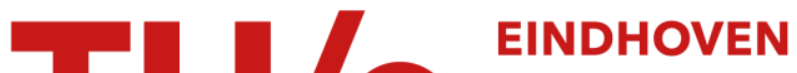 UNIVERSITY OF TECHNOLOGY
}

\section{Mathematical programming in The Netherlands}

Citation for published version (APA):

Dam, van, W. B., \& Tilanus, C. B. (1983). Mathematical programming in The Netherlands. (TH Eindhoven. THE/BDK/ORS, Vakgroep ORS : rapporten; Vol. 8310). Technische Hogeschool Eindhoven.

Document status and date:

Published: 01/01/1983

\section{Document Version:}

Publisher's PDF, also known as Version of Record (includes final page, issue and volume numbers)

\section{Please check the document version of this publication:}

- A submitted manuscript is the version of the article upon submission and before peer-review. There can be important differences between the submitted version and the official published version of record. People interested in the research are advised to contact the author for the final version of the publication, or visit the $\mathrm{DOI}$ to the publisher's website.

- The final author version and the galley proof are versions of the publication after peer review.

- The final published version features the final layout of the paper including the volume, issue and page numbers.

Link to publication

\section{General rights}

Copyright and moral rights for the publications made accessible in the public portal are retained by the authors and/or other copyright owners and it is a condition of accessing publications that users recognise and abide by the legal requirements associated with these rights.

- Users may download and print one copy of any publication from the public portal for the purpose of private study or research.

- You may not further distribute the material or use it for any profit-making activity or commercial gain

- You may freely distribute the URL identifying the publication in the public portal.

If the publication is distributed under the terms of Article 25fa of the Dutch Copyright Act, indicated by the "Taverne" license above, please follow below link for the End User Agreement:

www.tue.nl/taverne

Take down policy

If you believe that this document breaches copyright please contact us at:

openaccess@tue.nl

providing details and we will investigate your claim. 
MATHEMATICAL PROGRAMMING IN THE NETHERLANDS

by

W.B. van Dam and C.B. Tilanus

Report ARW 03 THE BDK/ORS/83/10

Preliminary and confidential

Based on a paper presented at ORSA/TIMS Joint National Meeting San Diego, 25-27 October 1982

September 1983
Eindhoven University of Technology Department of Industrial Engineering and Management Science Postbox 513 5600 MB Eindhoven Netherlands
EIBLIOTHEEK 8400738

T.SEINDHOVEN 
Mathematical programming in the Netherlands

by W.B. van Dam

Eindhoven University of Technology, Eindhoven, Netherlands

\section{Abstract}

Results of an exhaustive survey of mathematical programming in the Netherlands held in 1982 are presented and, where applicable, compared to a survey held in 1976. It appears that the growth rate has levelled off, that about half of the largest hundred industrial firms in the Netherlands now apply MP and that the users are quite satisfied with LP programs except for input, output and documentation.

1. Introduction

2. Organization of 1982 survey

3. Results for MP users

4. Results for LP models

5. Results for MP software 15

6. Summary and conclusions 19

References 
1. Introduction

In 1976, Müller conducted a survey of linear programming in the Netherlands $[1,2]$. One of the findings was that about half of the users had started LP in the last six years. The questions remained: how many users had quit LP in the last six years and what growth could be expected in the future? A natural consequence was to update and expand the survey about six years later. This has been done in 1982 .

This article presents the results of the 1982 survey of mathematical programing users, linear programming models and mathematical programming software. Where applicable, a comparison is made between the 1982 and 1976 surveys.

The order of presentation is as follows. An account of the 1982 survey is given in section 2, results for MP users in section 3 , results for LP models in section 4 , results for MP software in section 5 and a summary and main conclusions insection 6 . 


\section{Organization of 1982 survey}

The aim was to make an exhaustive survey of mathematical programing in the Netherlands with two categorical exceptions:

(1) Universities and other educational institutions were excluded because MP functions there as an educational end and not as a means of management.

(2) In the last few years, simple LP software had been introduced in the cattle-fodder industry on a large scale. The package Bestmix had already 57 users in the Netherlands. Only 6 of these were included in the 1982 survey to maintain comparability with the 1976 survey.

Otherwise, we tried to achieve completeness. To identify MP users, the following means were employed:

- Müller's address 1ist [1];

- In a questionnaire by telephone of 98 per cent of the personal membership of the Netherlands Society of Operational Research [3], respondents were asked if they applied MP or could name colleagues who did;

- Contact persons in universities and companies were questioned;

- Identified users were asked for names of other users, since MP users rarely work in isolation;

- Computer and software manufacturers were approached, but these would not generally dislose their clients.

In this way, a list of 112 addresses was made up. For a check, the list of the 100 largest companies quoted at the stock exchange, combined with the 75 unquoted, was considered [4]. Of the combinad 100 largest,

47 were already on the address list. Telephone calls were made to 15 of the remaining 53 and only one very recent starter, was discovered, whereupon this approach was abandoned. It was concluded that about half of the largest Dutch companies apply MP.

In mail surveys, response rates are generally low, in the order of 30 per cent. In order to get a high response rate, the following steps were taken:

- First, the right person at the user's address was found out and his consent to answer the questionnaire was obtained by telephone;

- Then, the questionnaire was sent for his personal attention;

- After one month, a first reminder call was made;

- After two months, a last reminder call was made. 
Thus, 86 per cent of the questionnaires sent out in May-June 1982 were returned by the deadline of 1 September (table 1). In 16 cases it turned out that no mathematical programming was used after a 11 - the misunderstanding being that the respondenthad thought that any computer proaramming of some mathematical computations was MP. The result was 78 usable questionnaires.

Table 1. Data about 1982 MP questionnaire

\begin{tabular}{lrl} 
Questionnaires sent out & 112 & $(100 \%)$ \\
Returned & 96 & $(86 \%)$ \\
Duplications (same company) & 2 & \\
No MP users after all & 16 & \\
MP users responding & 78 & \\
\hline
\end{tabular}




\section{Results for MP users}

Table 2 gives the main distribution of MP users by type of technique. Note that both MP and LP are conceived in a wide sense. Of all MP users, then, 86 per cent apply LP, and an unexpectedly high 23 per cent apply nonlinear programming or combinatorial programming techniques.

Table 3 gives the distribution by economic sectors. The primary sector, agriculture, is absent. Within the secondary sector (manufacturing industry) the process industries are strong and the assembly industries and construction are weak. The quartary sector accounts for a high 32 percentage of MP users.

Table 4 represents the immediate cause for this survey: the gross growth numbers of LP users. Apparently, there is continued growth. But the picture of 1982 looks more similar to the picture of 1976 than it really is. Of 19 users that professed to have started in the period 1977-1982, three already participated in the Müller survey. After transferring these, we find 16 starters in the period 1977-1982. Two respondents did not answer this question, but participated in Müller's survey. Assigning them to the Müller period, we find 50 starters up to 1976 according to the 1982 survey, and 48 according to the 1976 survey. So far so good, but among the 50 , we find 21 new names! Both surveys have only 29 users in common.

What happened to the 19 companies that responded in 1976, but were not included in the 1982 survey? Four of them were nonrespondents in 1982; one could not be contacted; three were anonymous in the 1976 survey, so they may be among the 21 new names; the remaining eleven explicitly confirmed that they had stopped using LP after 1976. Hence about one in four users observed in 1976 stopped after 1976. If the same ratio holds for the users overlooked in 1976, there must have been in fact about (21-3) $\times 4 / 3=24$ overlooked users, of whom 6 stopped after 1976 and were hence not included in the 1982 survey. This gives an estimated $11+6=17$ who stopped after 1976. On the other hand, recent starters are probably more easily overlooked than longstanding users, hence the 16 starters after 1976 may have been underestimated.

We conclude that, excepting the cattle-fodder industry in which there has been strong growth, net growth in the number of LP users after 1976 has been nil or little, and gross apparent growth has been mostly "changing of the guard".

The eleven that had stopped using LP in the last six years were asked 
for the reason why. The answers were quite elusive and unsatisfactory. They had just stopped. Because LP failed to be a successful tool of management or because the man who did it left the organization?

The sixteen that had started in the last six years were also asked for the reason why. The two main reasons given were:

- entrance into the organization of new employee(s) who introduced LP;

- financial attainability of hardware/software due to price decreases.

Table 5 compares the departments that are mainly responsible for the application of MP in the 1982 and 1976 surveys. In 1976, EDP departments had not been listed. We note that financial/administrative departments still play a minor part in MP.

Table 6 specifies the percentage distribution of nine MP subactivities between the staff group, who is mainly responsible for the application of MP, and the end user, who needs the end results of the MP exercises for his decision making. Note that in 6 per cent of the cases implementation does not take place. For the rest, the division of labour is not surprising.

Table 7 shows that the level of education of MP users has increased further still. Over one half is now university-trained, as opposed to only 3 per cent in the total working population.

Table 8 shows that regular education (by universities, etc.) has increased by fifty per cent as a source of MP know-how. But self-study has also increased, and courses have decreased - as a consequence of the depression?

Table 9 shows that the percentages of users who asked for external advice decreased in nearly all categories, especially in computer'software manufacturers (because of unbundling, i.e. selling hardware and software separately?). The percentage of users who asked nobody's advice increased to 40 . The main problems of users are in the areas of model building, model solving and software development.

Table 10, the last table with characteristics of MP users, specifies categories of computer facilities used. Nearly three quarters of MP users now use their own computer, an increase of the 1976 figure by fifty per cent. 
Table 2. Main distribution of MP users by type of technique

\begin{tabular}{lcc}
\hline Users of & Number & Percentage \\
\hline MP* & 78 & 100 \\
LP* & 67 & 86 \\
Nonl inear programming & 18 & 23 \\
Dynamic programming & 10 & 13 \\
Combinatorial techniques & 18 & 23 \\
\hline
\end{tabular}

* Mathematical programming is defined as any technique for solving optimization problems in management.

** Linear programming includes the techniques implemented in the standard "mathematical programming" packages with their options of mixed-integer programming, parametric programming, separable programming, etc.

Table 3. MP and LP users by economic sectors

\begin{tabular}{|c|c|c|c|c|c|}
\hline \multicolumn{2}{|c|}{ Sector } & \multicolumn{2}{|c|}{$\begin{array}{l}\text { MP users } \\
\text { number percentage }\end{array}$} & \multicolumn{2}{|c|}{$\begin{array}{l}\text { LP users } \\
\text { number percentage }\end{array}$} \\
\hline \multirow[t]{2}{*}{ II } & Manufacturing industry & 31 & 40 & 27 & 40 \\
\hline & (of which process industry*) & $(23)$ & $(29)$ & $(21)$ & (31) \\
\hline II I & Commercial services & 22 & 28 & 18 & 27 \\
\hline \multirow[t]{2}{*}{ IV } & Non-profit, government & 25 & 32 & 22 & 33 \\
\hline & & 78 & 100 & 67 & 100 \\
\hline
\end{tabular}

${ }^{\star}$ Food, cattle-fodder, chemical and oil industries. 
Table 4. When was LP started?

\begin{tabular}{ccc}
\hline Starting years & $\begin{array}{c}\text { Nuimber of LP users that started according to: } \\
1982 \text { survey }\end{array}$ & $\begin{array}{c}\text { 1976 survey } \\
\text { s } 1960\end{array}$ \\
\hline $1961-1965$ & 3 & 9 \\
$1966-1970$ & 13 & 11 \\
$1971-1976$ & 21 & 25 \\
$1977-1982$ & 19 & - \\
& 64 & 48 \\
\hline
\end{tabular}

Table 5. Which department is mainly responsible?

\begin{tabular}{lccc}
\hline Department & $\begin{array}{c}1982 \\
\text { number }\end{array}$ & $\begin{array}{c}\text { survey } \\
\text { percentage }\end{array}$ & $\begin{array}{c}1976 \text { survey } \\
\text { percentage }\end{array}$ \\
\hline Operations research & 22 & 33 & 46 \\
EDP/Informatics & 14 & 21 & - \\
Planning & 6 & 9 & 23 \\
Finance/Administration & 2 & 3 & 3 \\
Other & 22 & 33 & $\frac{29}{100}$ \\
Total & 66 & $\frac{100}{100}$ &
\end{tabular}


Table 6. Percentage distribution of MP activities between staff-group and end users

\begin{tabular}{|c|c|c|c|c|}
\hline Activity & Staff group & End user* & Both & Neither \\
\hline Problem definition & 22 & 24 & 51 & 3 \\
\hline Data collection & 21 & 52 & 24 & 3 \\
\hline Model building & 62 & 18 & 17 & 3 \\
\hline Model solving & 60 & 23 & 14 & 3 \\
\hline Evaluation of results & 9 & 31 & 60 & 0 \\
\hline Implementation & 33 & 22 & 39 & 6 \\
\hline Model maintenance & 41 & 19 & 30 & 10 \\
\hline Software development & 72 & 5 & 6 & 17 \\
\hline Software maintenance & 73 & 4 & 8 & 15 \\
\hline
\end{tabular}

*Defined as the one who needs the MP results for his own decision making. Percentages add up horizontally.

Table 7. Levels of education (percentages)

\begin{tabular}{lccc}
\hline Education & $\begin{array}{c}\text { Dutch working } \\
\text { population }\end{array}$ & $\begin{array}{c}1982 \text { survey } \\
\text { MP users* }\end{array}$ & $\begin{array}{c}1976 \text { survey } \\
\text { LP users* }\end{array}$ \\
\hline University & 3 & 56 & 46 \\
Higher professional & 8 & 29 & 34 \\
Other levels & $\frac{89}{100}$ & $\underline{15}$ & $\frac{20}{100}$ \\
\hline
\end{tabular}

*People who actually apply MP/LP. 
Table 8. Source of MP know-how (percentages)

\begin{tabular}{|c|c|c|c|c|c|}
\hline \multirow[t]{2}{*}{ Source } & \multicolumn{3}{|c|}{$\begin{array}{l}1982 \text { survey } \\
\text { sector }\end{array}$} & \multirow{2}{*}{ total } & \multirow[t]{2}{*}{$\begin{array}{c}1976 \text { survey } \\
\text { total }\end{array}$} \\
\hline & II & III & IV & & \\
\hline Regular education* & 30 & 45 & $\overline{61}$ & 45 & 30 \\
\hline External course & 11 & 10 & 6 & 9 & 17 \\
\hline Internal course & 20 & 12 & 4 & 12 & 33 \\
\hline \multirow[t]{2}{*}{ Self-study and practice } & 39 & 33 & 29 & 34 & 20 \\
\hline & 100 & 100 & 100 & 100 & 100 \\
\hline
\end{tabular}

*Universities, schools and other government-financed education.

Table 9. Advice asked

\begin{tabular}{lrcc}
\hline $\begin{array}{l}\text { From whom/ } \\
\text { About what }\end{array}$ & $\begin{array}{c}1982 \\
\text { number }\end{array}$ & $\begin{array}{c}\text { survey } \\
\text { percentage }\end{array}$ & $\begin{array}{c}1976 \text { survey } \\
\text { percentage }\end{array}$ \\
\hline From whom & 15 & 19 & 33 \\
\hline Universities & 15 & 19 & 48 \\
Computer/software manufacturers & 16 & 21 & 21 \\
Consultancy/service bureaus & 8 & 10 & 25 \\
Other MP users & 2 & 3 & 0 \\
Others & 31 & 40 & 15 \\
No advice asked & & & \\
About what & 15 & 19 & \\
Problem definition & 2 & 3 & \\
Data collection & 32 & 41 & \\
Model building & 24 & 31 & \\
Model solving & 4 & 5 & \\
Evaluation of results & 6 & 8 & \\
Implementation & 2 & 3 & \\
Model maintenance & 25 & 32 & \\
Software development & 11 & 14 & \\
Software maintenance & 2 & 3 & \\
Other problems & & & \\
\hline
\end{tabular}

${ }^{\star}$ Number of respondents: 78 . Some users asked multiple advice. 
Table 10. Which computing facilities were used?

\begin{tabular}{lccc}
\hline Facility & $\begin{array}{c}1982 \\
\text { number }\end{array}$ & $\begin{array}{c}\text { survey } \\
\text { percentage }\end{array}$ & $\begin{array}{c}1976 \text { survey } \\
\text { percentage }\end{array}$ \\
\hline Own computer & 63 & 72 & 46 \\
Computer manufacturer & 8 & 9 & 29 \\
Consultancy/service bureau & 7 & 8 & 9 \\
University & 10 & 11 & 14 \\
Other & 0 & 0 & $\frac{2}{100}$ \\
Tota ${ }^{*}$ & 88 & 100 & \\
\hline
\end{tabular}

${ }^{\star}$ Response: 77 ; some organizations use more than one facility. 


\section{Results for LP models}

Table 11 gives a specification by problem types of 184 LP models given by 56 LP users. Admittedly, what to count as a model is not well-defined. It was requested to consider all different model variants for one specific problem as one model. One repondent specifying 35 different models was not believed and excluded. Mixing and blending is the most frequent application of LP, especially if one takes account of the fact that the cattle-fodder companies included were limited to six. Production planning holds the second place and long range planning the third.

Tables 12-13 are based on characteristics asked from the users about one specific model, viz., the model they were most familiar with. Hopefully, these models provide a representative sample.

Table 12 specifies the frequency of use of LP models, the planning horizon in months, and the number of periods distinguished within the models. The results are not surprising. Planning horizon is roughly inversely proportional with planning frequency. In two thirds of the models only one period is distinguished.

Table 13 finally compares the sizes of the models in the 1976 and 1982 surveys. The criterion is the number of restrictions, but this is highly correlated with the number of variables [2]. We can cautiously conclude that both the percentage of small models ( $\leq 50$ restrictions) and the percentage of large models (> 500 restrictions) seem to increase. 
Table 11. LP models by problem types*

\begin{tabular}{|c|c|c|}
\hline Problem type & Number of models & Percentage \\
\hline Mixing, blending ${ }^{\star \star}$ & 34 & 18 \\
\hline Production planning & 31 & 17 \\
\hline Long term, strategic planning & 24 & 13 \\
\hline Location, allocation & 23 & 12 \\
\hline Distribution & 18 & 10 \\
\hline Purchasing & 16 & 9 \\
\hline Cutting stock & 8 & 4 \\
\hline Manpower planning & 7 & 4 \\
\hline Investment analysis & 7 & 4 \\
\hline Short term, corporate planning & 6 & 3 \\
\hline Costing, budgetting & 6 & 3 \\
\hline \multirow[t]{2}{*}{ Sequencing, scheduling } & 4 & 2 \\
\hline & 184 & 100 \\
\hline
\end{tabular}

* Response: 56 users; excluding one respondent specifying 35 models. ${ }^{\star *}$ Number of firms in cattle-fodder industry limited to 6. 
Table 12. Frequency of use, planning horizon, and number of periods distinguished in models, by problem areas

\begin{tabular}{|c|c|c|c|c|c|c|c|c|c|}
\hline \multirow[t]{2}{*}{ Problem area } & \multicolumn{3}{|c|}{$\begin{array}{l}\text { PTanning frequency } \\
\text { per year }\end{array}$} & \multicolumn{3}{|c|}{$\begin{array}{l}\text { Planning horizon } \\
\text { in months }{ }^{\star \star}\end{array}$} & \multicolumn{3}{|c|}{$\begin{array}{l}\text { Number of } \\
\text { periods in } \\
\text { model } s^{\star \star \star}\end{array}$} \\
\hline & $\leq 12$ & $13-99$ & $\geq 100$ & $<1$ & $1-12$ & $>12$ & 1 & $2-12$ & $>12$ \\
\hline $\begin{array}{l}\text { Long term, strate- } \\
\text { gic planning }\end{array}$ & 7 & 3 & 3 & 0 & 5 & 9 & 7 & 2 & 2 \\
\hline Location, allocation & 5 & 1 & 0 & 1 & 2 & 3 & 3 & 1 & 0 \\
\hline Production planning & 5 & 2 & 1 & 1 & 8 & 2 & 3 & 4 & 5 \\
\hline Distribution & 1 & 1 & 0 & 0 & 1 & 2 & 3 & 0 & 0 \\
\hline Mixing, blending & 0 & 5 & 12 & 6 & 4 & 1 & 11 & 2 & 0 \\
\hline
\end{tabular}

* Response: 46 models.

** Response: 45 models.

${ }^{* \star *}$ Response: 43 models.

Table 13. Size of LP models (percentage distribution)

\begin{tabular}{rcc}
\hline Number of restrictions & 1982 survey $^{\star}$ & 1976 survey $^{\star \star}$ \\
\hline$\leq 50$ & 25 & 21 \\
$51-150$ & 11 & 24 \\
$151-500$ & 34 & 34 \\
$>500$ & 30 & 21 \\
& 100 & 100 \\
\hline
\end{tabular}

* Response: 44 models.

${ }^{\star *}$ Response: 67 models. 


\section{Results for MP software}

Table 14 gives a survey of the MP software used. IBM is still the leader; the number of users (18) is the same as in 1976, but its market share has decreased.

Table 15 compares the non-default options (that have to be explicitly called upon by the user) in 1976 and 1982. There is little difference; perhaps the dominance of the options of initial starting base and mixed-integer programing is reinforced and the unimportance of parametric programming, generalized upper bounds, etc., is protruding.

Table 16 shows that even in tailor-made software LP is dominant.

Table 17 demonstrates the overwhelming position that Fortran holds in tailor-made MP software, in spite of all wishful thinking to the contrary.

Table 18, finally, gives a survey of complaints about standard LP software packages. For one reason or another. IBM's MPSX attracts more complaints than other software packages. This may explain its decreasing market share.

Most of the complaints refer to the manuals, the input and the output, not to the solution programs. The programs seem to have stabilized with few serious bugs left, although occasionally weird phenomena occur, like:

- an infeasible solution after feasibility has been attained;

- the dual algorithm stops after some iterations because the solution gets worse;

- more iterations with an initial starting basis than without;

- too many equalities cause a "permanent" phase I;

- an integer solution with a higher objective value than the continuous solution.

Nevertheless, the overall number of complaints about the standard LP software packages is so low that it does not seem worth-while to perform the intended analysis and testing of LP packages on criteria derived from users' criticisms. Instead, it looks promising to make a deeper analysis of the input and output sides of LP systems, of matrix generators and report writers, or generator generators, modelling languages, information systems, or whatever names they may be called, and to study cases of successful or unsuccessful implementation of LP models in the management of organizations. 
Table 14. Standard MP software packages

\begin{tabular}{llll}
\hline Package & Technique & Manufacturer & Number of users \\
\hline MPSX-370 & LP & IBM & 18 \\
APEX-III & LP & Control Data & 11 \\
Bestmix & LP & SCIA & 6 \\
NAG & LP/NLP & Numerical Algorithms Group & 5 \\
IMSL & LP/NLP & International Mathematical & 5 \\
& & and Statistical Libraries, Inc. & \\
MPOS & LP/NLP & $\begin{array}{l}\text { North-Western University, } \\
\text { Other packages mentioned } \leq \text { twice }\end{array}$ & 5 \\
Tailor-made, non-standard software & 10 \\
& & & 18 \\
\hline
\end{tabular}

* This software package together with a Wang-2200 minicomputer is sold by the Belgian software house SCIA mainly to cattle-fodder manufacturers. It had 57 users in 1982 in the Netherlands alone, but the number of firms in the 1982 survey has been restricted to 6 , for comparison with the 1976 survey. 
Table 15. Non-default options used (percentage of models)

\begin{tabular}{lcc}
\hline Option & 1982 survey $^{\star}$ & 1976 survey $^{\star \star}$ \\
\hline Initial basis & 39 & 37 \\
Mixed-integer programming & 32 & 29 \\
Reduction to smaller problem & 17 & 10 \\
Parametric programming & 14 & 22 \\
Generalized upper bounds & 8 & 12 \\
Separable programming & 3 & 3 \\
Decomposition methods & 2 & 3 \\
\hline
\end{tabular}

* Response: 59 models.

** Response: 73 models.

${ }^{\star \star \star}$ Sometimes implemented as option by default.

Table 16. Tailor-made software

\begin{tabular}{lc}
\hline Technique & Number of users \\
\hline LP & 20 \\
Non-linear programming & 8 \\
Combinatorial techniques & 9 \\
Dynamic programming & 2 \\
Heuristics & 3 \\
\hline
\end{tabular}


Table 17. Language used for tailor-made software

\begin{tabular}{lc}
\hline Language & Number of users \\
\hline Fortran & 31 \\
Simula & 3 \\
Algol & 2 \\
APL & 2 \\
Assembler & 2 \\
Basic & 2 \\
Pascal & 2 \\
\hline
\end{tabular}

Table 18. Dissatisfaction with standard LP software packages

\begin{tabular}{lrccc}
\hline Package & MPSX & APEX & 0ther packages & Total \\
\hline Number of respondents & 18 & 11 & 31 & 60 \\
Number of complaints about: & & & & \\
- input (organization) & 8 & 5 & 6 & 19 \\
- output & 8 & 1 & 7 & 16 \\
- user-friendliness & 3 & 2 & 10 & 15 \\
- bugs in program & 2 & 1 & 3 & 6 \\
- manuals/documentation & 12 & 5 & 15 & 32 \\
- user error handling & 3 & 1 & 3 & 7 \\
- weird phenomena & 6 & 0 & 2 & 8 \\
Total complaints & 42 & 15 & 46 & 103 \\
Compiaints/respondent ratio & 2.3 & 1.4 & 1.5 & 1.7 \\
\hline
\end{tabular}


6. Summary and conclusions

Results of a survey held in 1982 of mathematical programming applications in the Netherlands were presentedand, where applicable, compared with results of a survey held in 1976. Universities were excluded and the number of cattle-fodder firms, where an LP package for mixing and blending has been widely introduced in recent years, was limited to six. A response rate of 86 per cent was achieved.

The fifty per cent gross growth in users observed in 1976 for the period 1971-1976 seems to have levelled off to about thirty per cent gross growth for the period 1977-1982. However, net growth is estimated at little or nil, almost all apparent growth being mere "changing of the guard" (except for the cattle-fodder industry).

About half of the 100 largest Dutch companies now use MP. The process industries, like food, fodder, chemicals and oil, are well represented. The quartary sector is also well represented.

The level of education of MP users has still further increased and consultancy has decreased.

The classical short-term application areas like mixing and blending and production planning are still dominating but long-term, strategic, location and manpower studies are running up.

Both small models (up to fifty restrictions) and large (over five hundred restrictions) seem to hold their share.

The only non-default options that are widely used are initial starting basis and mixed-integer programming. If possible, their implementation in software packages should be perfected.

Complaints by users about the standard LP programs proper were few. Their criticisms focussed on the input side and the output side, the documentation, etc. Since LP software packages seem rather stabilized, further study could be devoted to LP model integration in the management of organizations. 


\section{References}

[1] Miiller, W., "Linear programming in the Netherlands" (in Dutch), Master's thesis, Eindhoven University of Technology, Eindhoven, 1977.

[2] Müller, W., and C.B. Tilanus, "Linear programmina from a management point of view, a survey, Netherlands, 1976", European Journal of Operational Research 2 (1978), 223-231.

[3] Tilanus, C.B., "Operations research in the Netherlands", Report BDK/ORS $/ 83 / 04$, Eindhoven University of Technology, Eindhoven, Netherlands, 1983.

[4] "The top-100 Dutch industrial companies quoted at the stock exchange, ranked by sales" and "The top-75 unquoted industrial companies" (in Dutch), NRC-Handelsblad 10 november 1981. 